\title{
Designing a Policy Mix and Sequence for Mitigating Agricultural Non-Point Source Pollution in a Water Supply Catchment
}

\author{
Brett A. Bryan • John M. Kandulu
}

Received: 29 March 2010 / Accepted: 8 November 2010 /

Published online: 25 November 2010

(C) The Author(s) 2010. This article is published with open access at Springerlink.com

\begin{abstract}
Agricultural non-point source pollution, common in water supply catchments worldwide, can have significant environmental and human health impacts, and its mitigation poses a challenge for policymakers. We used deliberative multi-criteria evaluation (DMCE) to identify a mix and sequence of policy instruments (or policy design) to address agricultural non-point source pollution using a case study of Cryptosporidium contamination in the Myponga River water supply catchment, South Australia. The major impediments to adoption of on-farm water quality management and benefits for ecosystem services were identified using a landholder survey for use as decision criteria in DMCE. The DMCE approach involved stakeholders in policy design during two community fora held in the catchment. We developed six policy scenarios and quantified their impact on decision criteria. The relative importance of decision criteria was quantified using swing weights and consensus was reached on the preferred policy scenario. The mix, sequence, and targeting of instruments in the preferred policy scenario were refined based on information obtained through the deliberative process. Impediments to adoption included a lack of both information/knowledge and financial resources. The recommended policy scenario involved targeted information, followed by an incentive program, and finally the regulation of a mandatory code of practice for water quality management. Detailed, catchmentspecific context obtained through DMCE was critical for refining an effective mix and sequence of policy instruments. The techniques may be readily used to select and schedule policy instruments for effective mitigation of agricultural non-point source pollution in other drinking water supply catchments elsewhere.
\end{abstract}

Keywords Water quality $\cdot$ Participatory $\cdot$ Watershed $\cdot$ Catchment $\cdot$ Ecosystem services $\cdot$ Cryptosporidium

B. A. Bryan $(\varangle)$. J. M. Kandulu

CSIRO Ecosystem Sciences, PMB 2 Glen Osmond,

South Australia, 5064, Australia

e-mail: brett.bryan@csiro.au 


\section{Introduction}

Non-point source pollution is a significant source of water quality impairment in many countries (Huang and Xia 2001; Collins et al. 2007) including Australia (Jansen and Robertson 2001). Pathogens such as Cryptosporidium are a particularly important pollutant in water supply catchments because of the risk posed to human health (MacKenzie et al. 1994; Hrudey and Hrudey 2004; Bewsell et al. 2007). Extensive livestock agriculture is a significant source of Cryptosporidium in surface water (Ferguson et al. 2007). Catchment-based actions such as reducing livestock access to streams, riparian restoration and erosion control programs, and manure and effluent management (Bewsell et al. 2007; Collins et al. 2007) can cost-effectively mitigate Cryptosporidium risk, enhance water quality, and produce a range of other ecosystem services (Lovell and Sullivan 2006; Bryan and Kandulu 2009; Chang et al. 2010).

However, there are many factors influencing the adoption of on-farm water quality management measures by landholders (Rhodes et al. 2002; MacGregor and Warren 2006; Kim et al. 2008; Prokopy et al. 2008; Greiner et al. 2009). The relative significance of these impediments can vary both between catchments and between individual farmers within catchments (Pannell et al. 2006; Bewsell et al. 2007). Agricultural non-point source pollution can be most effectively controlled by focusing policy instruments (e.g. regulatory standards, economic incentives, and suasive mechanisms) on these impediments and determinants of adoption of desired management practices (Horan and Ribaudo 1999; Sterner 2003; Prokopy et al. 2008). However, often, little is known about these determinants (Ma et al. 2009) or the effectiveness of policy instruments in addressing them (Connor et al. 2008b). There is a need to understand key determinants of adoption of water quality management and the careful selection and scheduling of policy instruments (or policy design) for addressing them for the effective mitigation of agricultural non-point source pollution.

Recent studies have proposed methods for selecting environmental policy instruments to address context-specific impediments to adoption. Romstad (2004) and Pannell (2008) provide approaches for selecting policy instruments for conservation based on economic characteristics of the problem such as the net private versus public benefits resulting from management. Using a qualitative assessment based on economic theory, Bewsell et al. (2007) identified that policy instruments enhancing on-farm benefits and supported by regulation could effectively increase the adoption of water quality management. Connor et al. (2009) developed a screening process for selecting market-based instruments for mitigating agricultural non-point source pollution. Ward et al. (2008) demonstrated the utility of multi-criteria evaluation (MCE) to suggest policy features for overcoming a range of impediments to the efficient functioning of market-based instruments for mitigating dryland salinity. As an extension to MCE, participatory or deliberative multi-criteria evaluation (DMCE, Proctor and Drechsler 2006; Renn 2006) has a special focus on capturing the arguments and reasoning used by participants in MCE (Stirling 2006; MacLeod et al. 2007). DMCE has potential to further enrich understanding of the context of agricultural non-point source pollution for both decision-makers and stakeholders (Mustajoki et al. 2004; Proctor and Drechsler 2006; Renn 2006) and thereby assist policy design for enhancing adoption of on-farm water quality management. 
In this study, we designed a policy mix and sequence for addressing the most important impediments to adoption of water quality management using a landholder survey and DMCE. The policy design process involves five steps: (1) identify impediments to adoption and benefits of water quality management using a landholder survey; (2) specify policy scenarios for overcoming impediments for use as alternatives in DMCE; (3) quantify the impact of policy scenarios on overcoming impediments to adoption and achieving water quality and other benefits; (4) weight the relative importance of the impediments to, and benefits of, on-farm water quality management and identify the preferred policy scenario; and (5) refine the preferred policy scenario based on detailed, catchment-specific contextual understanding of water quality management issues obtained through the deliberative process. We applied these techniques to a case study of Cryptosporidium contamination in the Myponga water supply catchment in South Australia. We discuss the use of these techniques for policy design for addressing agricultural non-point source pollution more broadly.

\section{Study Area}

The Myponga Reservoir supplies drinking water to more than 50,000 people in the southern Fleurieu Peninsula, South Australia (Fig. 1). The 28 GL reservoir is entirely fed by the $123 \mathrm{~km}^{2}$ catchment of the Myponga River.

Extensive land use, mostly beef cattle grazing and lifestyle amenity, occurs over $61 \%$ of the catchment and dairying occurs on approximately $13 \%$. Recent trends have seen the subdivision of dairy farms and conversion to smaller lifestyle properties. Our study focuses on properties that are both grazed by livestock and are traversed by water courses which total 6,115 ha (49\% of the study area). Within this area there are 146 property titles $>1$ ha in size that run livestock with a median property size of 27.4 ha and largest property size of 687 ha. The 32 larger commercial properties ( $>50$ ha) cover 3,905 ha $(64 \%$ of the broad acre grazing area), with the remainder being smaller hobby farms and lifestyle properties. Many landholders own and share-farm multiple properties.

The unfettered access of livestock to water courses is a major factor causing the elevated concentrations of human-infectious Cryptosporidium in source water entering the Myponga reservoir (Bryan et al. 2009). Water-borne Cryptosporidium infection can cause severe gastrointestinal illness in humans that can potentially be life-threatening. The water utility SA Water has obligations to manage source water quality in Myponga under the multi-barrier paradigm adopted under the Australian Drinking Water Guidelines (NHMRC 2004).

The Adelaide and Mt. Lofty Ranges Natural Resources Management Board (AMLR NRM Board) offers information to landholders through its Land Management Program. Modest financial incentives have been provided by the South Australian Environment Protection Authority and the AMLR NRM Board for land and water resource management (Connor et al. 2008a) and tax deductions are available for primary producers who undertake water course management (ATO 2008). Minimum environmental duty regulations oblige landholders not to pollute waterways under the Environment Protection Act 1993 (Section 25) and the Natural 


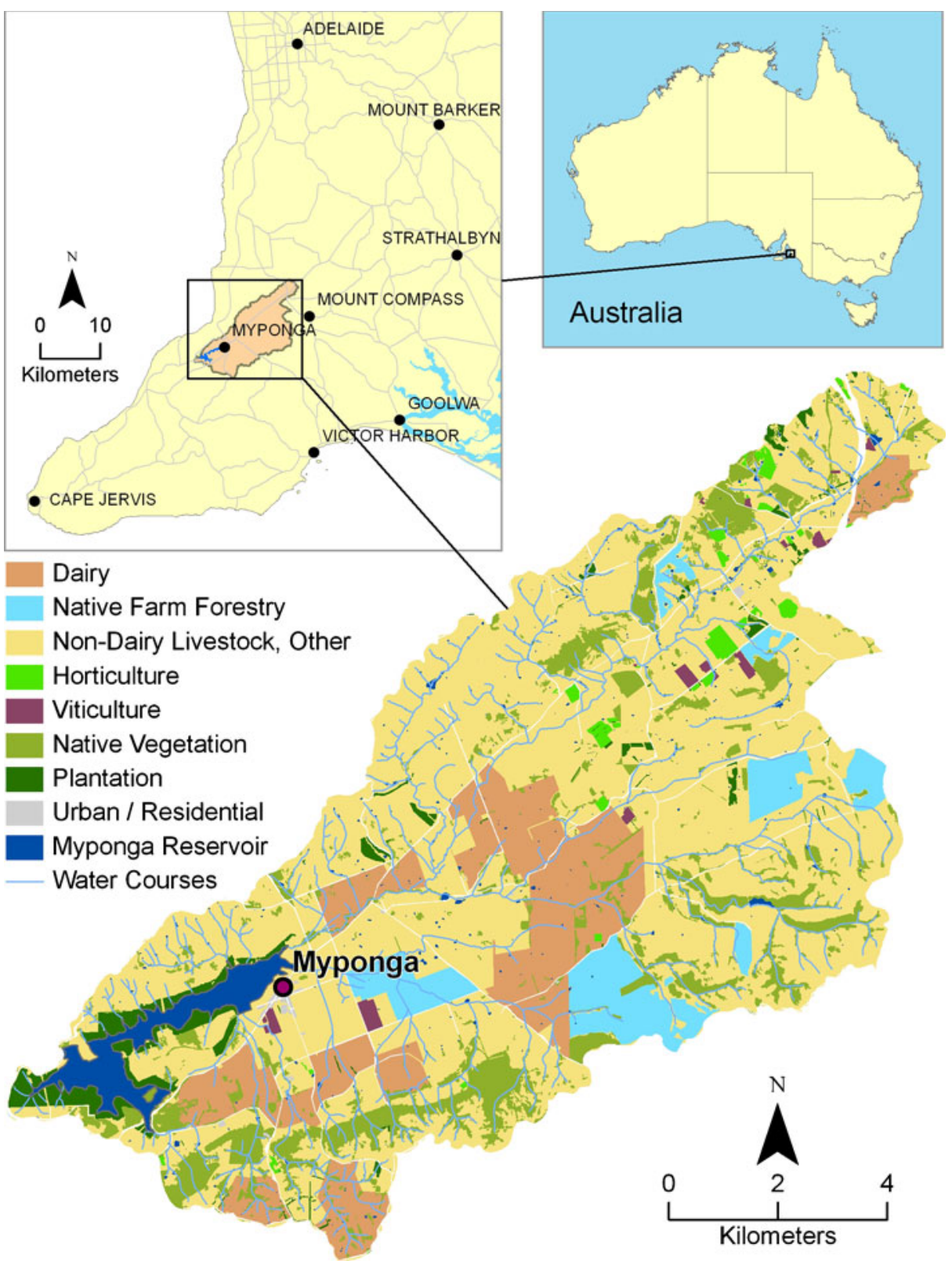

Fig. 1 Location and land use map of the Myponga River catchment study area

Resources Management Act 2004 (Section 131). Since 2000, government programs have had some success in motivating adoption of a range of on-farm water quality management practices, especially by dairy farmers (EPA 2008; Bryan et al. 2009). However, adoption rates amongst non-dairy landholders including the beef cattle 
industry, sheep graziers, lifestyle properties, and hobby farmers were low (Bryan et al. 2009). Bryan et al. (2009) and Bryan and Kandulu (2009) found that restricting the water course access of non-dairy cattle could cost-effectively reduce Cryptosporidium export to the Myponga reservoir by around $90 \%$ and produce a range of other ecosystem service benefits for water quality, biodiversity, and carbon sequestration (Lovell and Sullivan 2006; Bryan and Kandulu 2009).

\section{Methods and Results}

\subsection{Identifying Decision Criteria}

We identified impediments to the adoption of water quality management practices in face-to-face interviews with 36 landholders in the Myponga River catchment. Landholders were selected by the South Australian Environmental Protection Authority (EPA) and the DairySA industry group to provide a sample representative of the range of land uses from across the catchment. Participants included all 16 dairy farmers, 13 broad scale graziers, one blue gum plantation owner, two horticulturalists, one equestrian property owner, and three hobby farmer/lifestyle landholders. In aggregate, participants managed more than $60 \%$ of the catchment by area. The interview included more than 50 questions on a range of topics, in particular, the motivators of, and impediments to adoption of water quality management practices (see Online Supporting Material). Six major impediments to the adoption of onfarm water quality management practices were identified from the survey responses (Table 1) and included in the DMCE as decision criteria.

In addition, Financial Resources (Government) was included as a decision criterion as some stakeholders considered on-farm management to be the responsibility of landholders (i.e. polluter pays) and the subsidisation of private, on-farm management an inappropriate use of public money. Five ecosystem service benefits were also identified as being potentially important or valuable from the landholder survey and a previous cost-benefit analysis (Bryan and Kandulu 2009) and included as decision criteria. These included water quality, biodiversity, carbon sequestration, health risk mitigation, and landscape amenity services (see Bryan and Kandulu 2009).

\subsection{Identifying Instruments and Developing Policy Scenario Alternatives}

We identified alternative policy instruments for addressing the six major impediments to adoption of water quality management based on published policy selection guidelines and case studies for mitigating non-point source pollution (Table 2; Sterner 2003; Harrington et al. 2004; BDA Group and EconSearch 2005).

We then developed policy scenarios in consultation with community stakeholders in the Myponga River catchment. We held a community forum in Myponga attended by 10 local landholders (55 were invited) in addition to project partner agency representatives (CSIRO, EPA, SA Water, DairySA, and AMLR NRM Board). During the forum, the sources and solutions of the water quality problem in the Myponga catchment were discussed and the policy design process was introduced. We then defined six policy scenarios (potential policy alternatives for achieving water 
Table 1 Impediments to the adoption of water quality management practices in the Myponga River catchment identified in the landholder survey

\begin{tabular}{|c|c|}
\hline Description of impediment & Significance in the catchment \\
\hline $\begin{array}{l}\text { Knowledge access-lack of awareness of } \\
\text { impacts of land use activities and } \\
\text { knowledge of how to undertake water } \\
\text { quality management practices }\end{array}$ & $\begin{array}{l}2 \text { dairy and } 3 \text { non-dairy respondents } \\
\text { required on-farm extension programs } \\
\text { on fencing to progress } \\
2 \text { dairy and } 2 \text { non-dairy livestock } \\
\text { respondents required information } \\
\text { on fencing to progress }\end{array}$ \\
\hline $\begin{array}{l}\text { Workforce availability/labour scarcity-limited } \\
\text { availability of labour and time to undertake } \\
\text { on-ground works, especially in the } \\
\text { absence of adequate incentives }\end{array}$ & $\begin{array}{l}4 \text { dairy and } 5 \text { non-dairy respondents } \\
\text { cited a shortage of time } \\
\text { to undertake fencing }\end{array}$ \\
\hline $\begin{array}{l}\text { Trainer/advisor proficiency_limited } \\
\text { availability of knowledgeable and } \\
\text { experienced advisors as a major } \\
\text { impediment to adoption }\end{array}$ & $\begin{array}{l}1 \text { dairy and } 2 \text { non-dairy respondents } \\
\text { expressed lack of confidence in } \\
\text { information provided by advisors and } \\
\text { rely on own knowledge \& experience } \\
\text { to make farm decisions }\end{array}$ \\
\hline $\begin{array}{l}\text { Organisational strength-lack of structural } \\
\text { and institutional arrangements for support } \\
\text { of adoption through industry groups } \\
\text { or social networks }\end{array}$ & $\begin{array}{l}6 \text { respondents said they are motivated } \\
\text { by programs driven by industry bodies }\end{array}$ \\
\hline $\begin{array}{l}\text { Regulatory support/impediment-absence of } \\
\text { appropriate regulatory support mechanisms } \\
\text { and the need to remove regulatory impediments }\end{array}$ & $\begin{array}{l}3 \text { dairy and } 4 \text { non-dairy respondents cited } \\
\text { allowing crash grazing would progress } \\
\text { fencing activities. Aligning legislation/ } \\
\text { regulation with appropriate enforcement } \\
\text { mechanisms and removing prohibitive } \\
\text { regulation would enhance adoption } \\
\text { in the area }\end{array}$ \\
\hline $\begin{array}{l}\text { Financial resources (landholders)_adoption of } \\
\text { water quality management has a high } \\
\text { direct cost and poses a risk to farm income }\end{array}$ & $\begin{array}{l}5 \text { dairy and } 9 \text { non-dairy respondents } \\
\text { cited lack of financial resources } \\
\text { and insufficient incentives }\end{array}$ \\
\hline
\end{tabular}

quality and human health objectives in the catchment over 20 years) for inclusion in the DMCE process:

Status Quo Existing policy continues unchanged (Section 2). Little increase in adoption of water quality management practices occurs and water quality continues at same poor/unsatisfactory level (EPA 2008; Bryan et al. 2009).

Suasion Existing incentives and regulation are complemented by a dramatic increase in the amount of information provided to landholders through awareness raising, education and information, and recognition. The cost of adoption is largely borne by landholders and cost of policy implementation is borne by government. A limited increase in adoption of water quality management and associated improvement in water quality is expected (BDA Group and EconSearch 2005).

Incentives Existing regulations are complemented by a range of financial incentives for land stewardship such as auctions, payments schemes, subsidies, and rebates. This is supported by a limited increase in education and awareness. The cost of adoption is 
Table 2 Policy instruments suitable for addressing specific impediments to adoption of water quality management practices

\begin{tabular}{ll}
\hline Impediment & Potential policy solutions \\
\hline Knowledge access & $\begin{array}{c}\text { Suasion: general education programs; guidelines and codes } \\
\text { of practice; training programs; extension services } \\
\text { Incentives: public provision of contractor services; } \\
\text { Workforce availability/ } \\
\text { labour scarcity }\end{array}$ \\
$\begin{array}{l}\text { subsidised contractor services; accreditation schemes; } \\
\text { stewardship schemes; subsidies and grants; rebates }\end{array}$ \\
$\begin{array}{l}\text { Suasion: advisor training and performance monitoring schemes } \\
\text { Organisational strength }\end{array}$ & $\begin{array}{l}\text { Suasion: industry codes of practice; incentives: subsidised } \\
\text { information campaigns by industry associations; public-funded }\end{array}$ \\
information campaigns by industry associations \\
Regulatory support/ & Regulation: process-based standards; licensing; mandatory \\
impediment & management plans; placing a ban on risky farm practices \\
& and acquisition; removing prohibitive regulation \\
Financial resources & Incentives: accreditation schemes; stewardship payment \\
& schemes; subsidies and grants; public provision \\
\hline
\end{tabular}

shared by landholders and government, with the cost of policy implementation borne by government. A moderate increase in adoption of water quality management and associated improvement in water quality is expected (Rhodes et al. 2002; Pannell et al. 2006).

Regulation Existing regulations are strengthened to enforce the uniform adoption of water quality management through the introduction of legislative controls, standards, bans on degrading practices, and compliance monitoring. These are supported by limited education and information, and financial incentives. Costs of adoption are largely borne by landholders with some contribution by government with the costs of policy implementation and compliance monitoring borne by government. The increase in adoption and resultant water quality improvements are expected to be very high (BDA Group and EconSearch 2005).

Buy Back Involves the purchase of livestock properties across the catchment at market price by government and subsequent removal of livestock and conversion to carbon forest. This process is complemented by a communication and awareness campaign. The costs of property purchase and policy implementation are borne by government. The increase in adoption and resultant water quality improvements are very high.

Policy Mix This includes suasion, incentives, and regulation sequenced in a way that is likely to motivate adoption through addressing impediments. For example, suasion and education first, followed by a broad incentives program and supported by a robust regulatory framework. The cost of adoption is shared by landholders and government, with the cost of policy implementation borne by government. The increase in adoption and resultant water quality improvements are expected to be high (BDA Group and EconSearch 2005). 


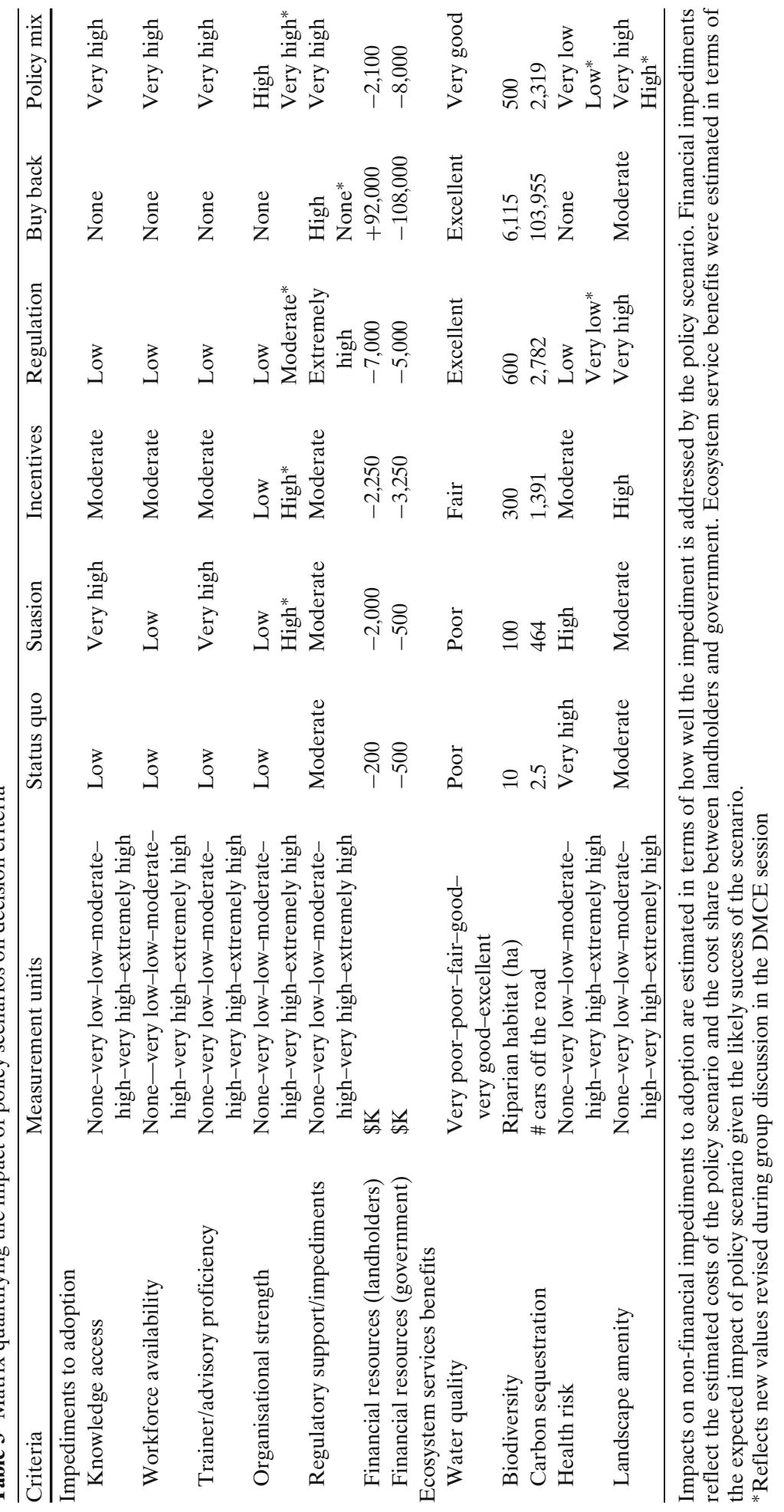




\subsection{Quantifying the Impact of Policy Scenarios on Criteria}

The impact of each policy scenario on each decision criterion (Table 3) was calculated using a variety of techniques. The impact of policy scenarios on overcoming non-financial impediments to adoption was estimated based on contextual knowledge of the catchment from the landholder survey, the first community forum, and the results of a policy impact study conducted in the case study area (BDA Group and EconSearch 2005).

Financial and ecosystem service impacts of the Status Quo scenario were summarised from expenditure and adoption rates in the catchment since 2001 (EPA 2008). The Regulation scenario was considered to result in the management (i.e. livestock access restriction and riparian restoration) of all water courses on livestock properties in the catchment. Financial cost and ecosystem service benefits were taken from Bryan and Kandulu (2009).

The Suasion, Incentives, and Policy Mix scenarios were considered to be less effective than Regulation in motivating adoption. The financial and ecosystem service impacts for these scenarios were estimated based on their expected success relative to that achieved by the Regulation scenario. Financial costs under the Buy Back scenario were calculated based on the purchase of all livestock properties with water course access totalling 6,115 ha. A median price of $\$ 15,000 /$ ha was used on the basis of sales data from 68 local properties over 20 ha sold between 2005 and 2008. Landscape amenity impacts were estimated based on the scenic beauty and recreation potential of the likely outcome of the policy scenario.

\subsection{Deliberative Multi-Criteria Evaluation}

A process of deliberative multi-criteria evaluation (Proctor and Drechsler 2006) of policy scenarios was undertaken with stakeholders in the Myponga River catchment during a second community forum in Myponga. Stakeholders were invited by mail and telephone, and through an open invitation published in a local newspaper. A total of 14 people attended the forum. Six local landholders participated in the DMCE session including five that attended the first forum. This group included one dairy farmer, one ex-dairy farmer, one sheep hobby farmer, one beef hobby farmer, and two mixed farmers. To support the decision-making of the group two local natural resource management representatives and six representatives from project partner agencies with expertise in water quality, catchment and land management, and economics and policy were also present. The aim of the community forum was for the local stakeholders to arrive at a consensus view of the best policy alternative to address water quality objectives in the Myponga catchment.

After the initial stakeholder review of the impact scores (Table 3) the group was satisfied with the criteria, policy scenarios, and the impact matrix. The Buy Back policy scenario was ruled out early on due to high economic and social costs. Quantitative MCE was then undertaken using the Logical Decisions software (Smith 2007). Participants were asked to weight the relative importance of each of the 12 decision criteria (Table 3) using swing weights (von Winterfeldt and Edwards 1986). Deriving weights was an iterative process where swing weights were repeatedly revised as new information came to hand through discussion between group members and through interactions with experts until consensus was reached. 
To identify the best policy scenario alternative a multi-attribute utility theorybased weighted summation approach was used (Zanakis et al. 1998). Let $I$ be the set of five policy scenario alternatives, $J$ be the set of 12 decision criteria, and $x_{i j}$ be the impact of each policy scenario $i$ on each decision criterion $j$ (see Section 3.3). The first step was to linearly transform swing weight scores $w_{j}$ to weights $w_{j}^{\prime}$ which sum to 1 over all criteria $j$ in $J$ :

$$
w_{j}^{\prime}=\frac{w_{j}}{\sum_{j \in J} w_{j}}
$$

Then, the raw impact scores $x_{i j}$ were converted into utility scores $u_{i j}$ where $0 \leq u_{i j} \leq 1$ using a linear transform. Policy scenario alternatives were then ranked and the best alternative selected based on maximum multi-attribute utility $U_{i}$ where:

$$
U_{i}=\sum_{j \in J} w_{j}^{\prime} u_{i j}
$$

In the DMCE session, the above process was conducted live and presented to the participants who unanimously accepted the policy scenario ranking.

During the DMCE session, detailed, context-specific information on issues surrounding water quality management in the Myponga River catchment was captured. This information was used to refine the composition and scheduling of instruments in the preferred policy scenario alternative.

\subsection{Results of Multi-Criteria Evaluation}

Five criteria were considered to be equally most important including Knowledge Access, Trainer/Advisor Proficiency, Financial Resources (Landholders), Biodiversity, and Health Risk (Fig. 2). With a multi-attribute utility score over all criteria of 0.779 , the policy mix scenario was the highest ranked policy scenario alternative. The Regulation $\left(U_{i}=0.558\right)$, Incentives $\left(U_{i}=0.527\right)$, and Suasion $\left(U_{i}=0.525\right)$ scenarios were next highest ranked, with the Status Quo $\left(U_{i}=0.376\right)$ ranked lowest. Sensitivity analysis demonstrated the robustness of the highest ranked Policy Mix alternative to changes in weights of the five most influential decision criteria. Criteria weights had to be increased to at least $65 \%$ before the Policy Mix scenario was outranked as the preferred scenario (Fig. 3).

\subsection{Refinement of the Policy Mix Scenario}

We synthesised and used the contextual detail obtained during the DMCE to refine the mix and sequencing of policy instruments in the preferred Policy Mix scenario and motivate the widespread adoption of water quality management in Myponga. Policy instrument sequencing followed the principle that starting with less interventionist measures (encouragement) followed and complemented by more interventionist measures (enforcement) is more equitable and acceptable to the community (Gunningham and Sinclair 2005). We also tried to address the most significant impediments to adoption first. 


\section{Please enter the swing weights for Best Policy Scenario \\ Swing weights must be between 0 and 100 . One stving should equal 100. Swings indicate importance of going from least to most preferred level}

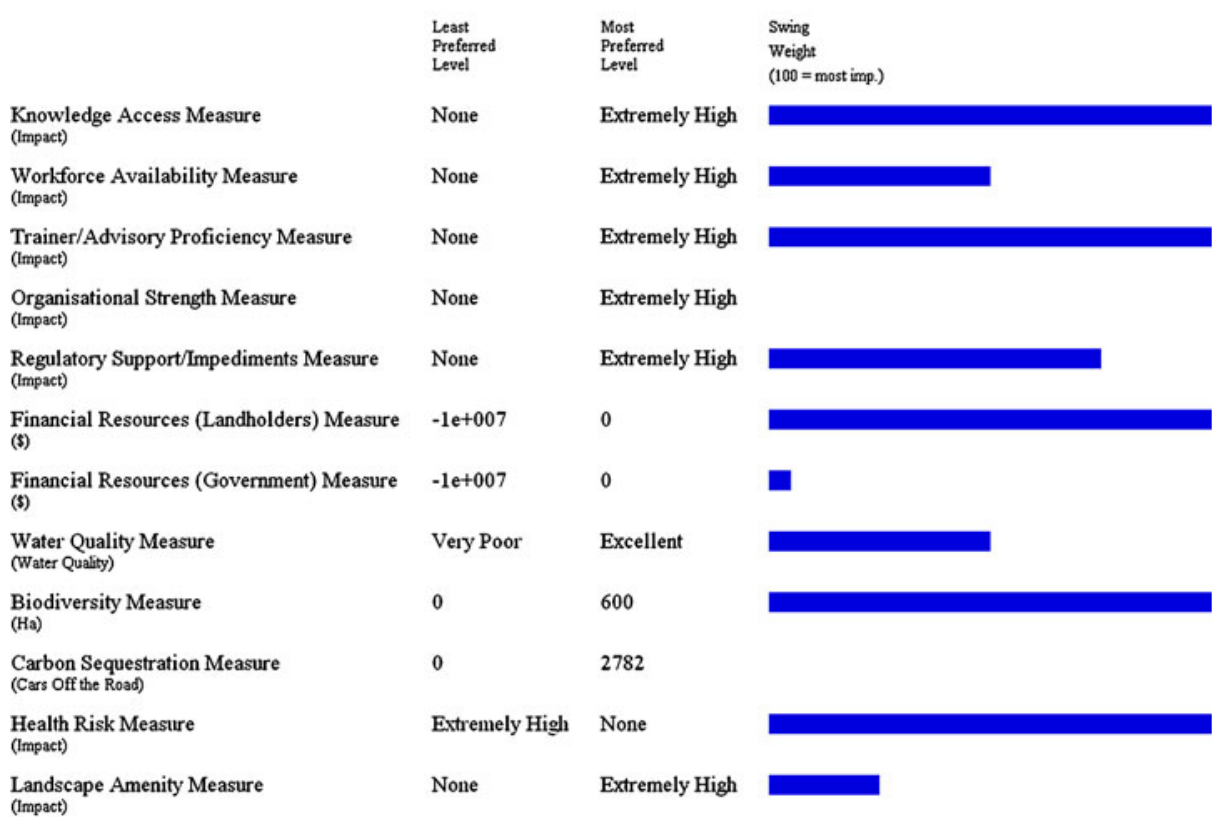

Fig. 2 Final consensus on swing weights $w_{j}$ on decision criteria illustrated using the actual interface in Logical Decisions presented to participants in the DMCE session in Myponga

\subsubsection{Specific Context of the Water Quality Problem}

Group discussion explored in-depth a perceived disparity that professional farmers had a much lower the impact on water quality than hobby farmers, corroborating the findings of the landholder survey. Hobby farmers were often known to engage in a range of unsustainable land use and management practices including overstocking, allowing unfettered livestock access to water courses, and a lack of herd rotation. These practices were seen as resulting from a lack of information, advice, know-how, and interest in sustainable land management by hobby farmers. The group perceived that tax deductions available to primary producers provide a perverse incentive for hobby farmers to increase stocking densities beyond carrying capacity.

\subsubsection{Information and Suasion}

There was a general desire amongst DMCE participants for more specific information on water quality management techniques. An effective information strategy may include a broad education and awareness campaign around issues of overstocking and riparian management delivered through local media. This could be complemented by extension services and landholder training targeted at properties where more stock have access to water courses (Bryan and Kandulu 2009). Despite the 


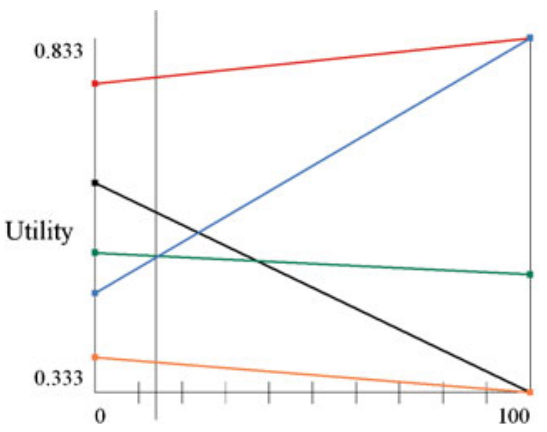

Percent of Weight on Knowledge Access Measure

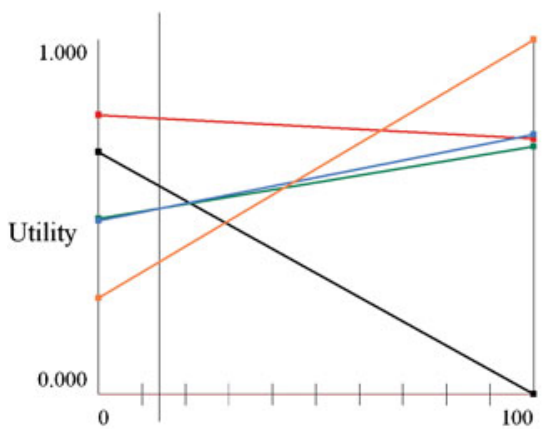

Percent of Weight on Financial Resources (Landholders) Measure

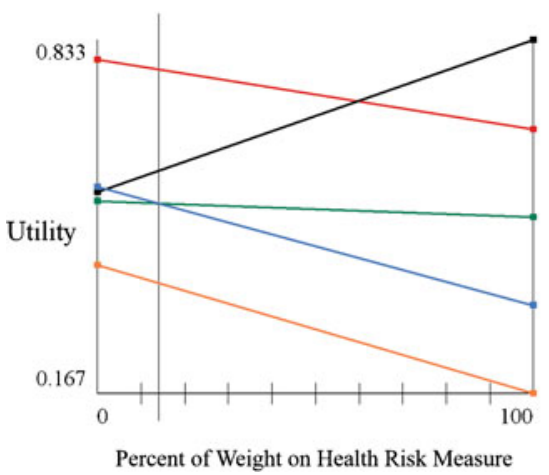

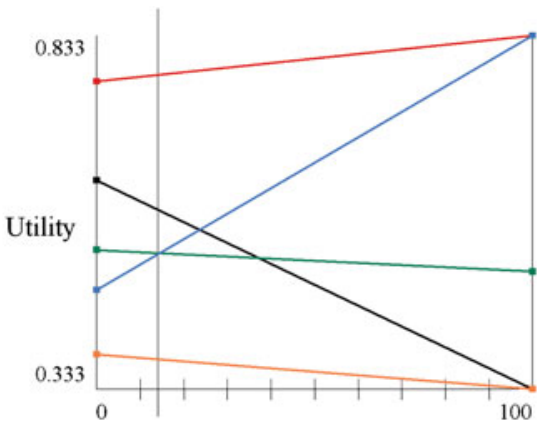

Percent of Weight on Trainer/Advisory Proficiency Measure

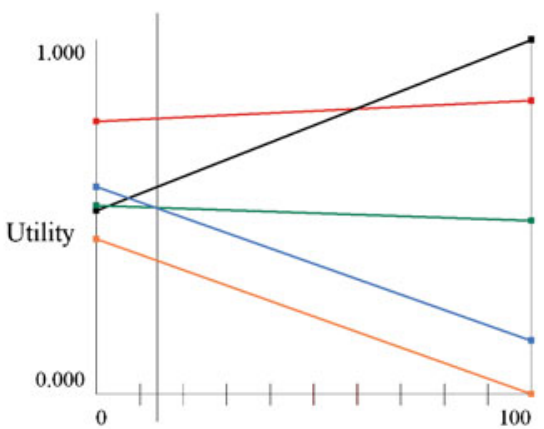

Percent of Weight on Biodiversity Measure

Fig. 3 Sensitivity of the ranking of policy scenario alternatives to changes in weights of the five most highly weighted (swing weight $=100$ ) decision criteria. The vertical line reflects the normalised weight $w_{j}^{\prime}$ for each criteria

higher cost to government, this approach has been demonstrated to be effective in enhancing adoption (EPA 2008).

However, there was concern that suasive instruments risk failure because hobby farmers show little interest in participating and have little support from social networks. In addition, the high turn-over rate of lifestyle properties in the catchment means that suasive efforts will need to be ongoing. In this case, more structured instruments such as the development of a code of practice for sustainable land use and management in water supply catchments, enforced later through regulation, 
may be more effective. The code of practice would include guidelines on best practice management of livestock, water courses, riparian zones, and effluent. This information could be delivered through programs tailored for hobby farmers such as the Western Australian Government's Small Landholder Information Service (Government of Western Australia 2010).

These suasive instruments should occur first in the scheduling of policy instruments. Suasive measures are likely to encourage some adoption very cheaply and provide an essential informational buttress for other policy instruments.

\subsubsection{Economic Incentives}

Survey results and discussion in the DMCE suggest that economic incentives need to form the core policy instrument for enhancing the adoption of water quality management. The use of incentives involves both the removal of perverse incentives and the establishment of payment schemes. Perverse taxation incentives may be corrected by requiring that landholders comply with a land management code of practice to be eligible for deductions. Incentives may occur simultaneously with or follow the suasive instruments above.

As the cost to landholders was found to be a much stronger impediment to adoption than cost to government, a beneficiary pays cost-sharing arrangement may be most effective in enhancing adoption. This may involve all of the administration and implementation (monitoring and enforcement) costs of an incentives program, and the bulk of the direct costs of water quality management being borne by government or the water utility. Market-based incentives programs may be used to capture the private cost-share from landholders (Connor et al. 2008a, 2009; Ward et al. 2008) and use existing spatial metrics to target properties impacting most on water quality (see Bryan and Kandulu 2009).

\subsubsection{Regulation}

Participants agreed that stronger regulation and enforcement was an essential component of an effective policy mix. Participants felt strongly that regulatory institutions needed to incorporate practical flexibility for land management such as allowing crash grazing (a short, intense grazing period during summer).

A mandatory code of practice for land use and management in water supply catchments may be most effective in Myponga. The code of practice combines the suasive benefits of increased education and awareness with the enhanced certainty of regulation. Monitoring and enforcement of compliance may be relatively simply done (e.g. by aerial survey or farm visits) although this presents an ongoing cost to government when there are many small landholders. Information and incentives are required to support regulatory requirements of landholders.

The mandatory code of practice may be applied immediately to properties undergoing a change of ownership to oblige new landholders to comply. However, given the heterogeneous distribution of Cryptosporidium sources in the catchment (Bryan and Kandulu 2009) uniform regulation risks imposing high costs on some landholders with little benefit for water quality (Gunningham and Sinclair 2005; Strauss et al. 2007). To minimise this impact, full implementation of regulation such as a mandatory code of practice needs to come last in the sequence. In this way, 
the major contributors to the water quality problem can be addressed more costeffectively through suasion and incentive-based measures.

\subsubsection{Other Minor Policy Features}

Government-funded land buy back and land use change may be appropriate on a voluntary case-by-case basis. Some landholders also indicated a willingness to restructure farms from livestock to other more sustainable land uses.

\section{Discussion}

Policy design in this study involved tailoring a mix of policy instruments to effectively address impediments to adoption of water quality management. Most existing studies addressing impediments to adoption of water quality management have tended to evaluate policy instruments individually and not as part of a broader mix of instruments (Connor et al. 2008a, 2009; Loomis and Allen 2008; Muller et al. 2009; Muller and Mendelsohn 2009; Ward et al. 2008). The policy mix harnesses the strengths of individual policy instruments while compensating for their weaknesses by the use of additional complementary instruments (Gunningham and Sinclair 2005; de Loë and Bjornlund 2008). Our results are also consistent with other studies (Gunningham and Sinclair 2005; de Loë and Bjornlund 2008; Sarker et al. 2008) which found that a mix of policy instruments is more likely to outperform any single instrument especially where there are multiple impediments to adoption. The sequencing of policy instruments is probably as important as the instrument mix and targeting. We followed the two principles that effective policy: employs less interventionist measures first, and; addresses the most important impediments to adoption first. These two principles were complementary in our case study (suasion and incentives were suggested to address the impediments of Knowledge Access, Trainer/Advisor Proficiency, Financial Resources (Landholders)). However, in some other catchments these principles may conflict (e.g. the most important impediment may need to be addressed by regulation). Some pragmatic compromise between these principles may be required in some catchments.

Critical to the mix, sequencing, and targeting of policy instruments is the need for a detailed understanding of the catchment-specific context of the water quality problem. In line with other studies (Davies and Hodge 2006; Bewsell et al. 2007; Kim et al. 2008) the landholder survey was found to be a useful tool for identifying the attitudes, impediments and drivers of management adoption amongst landholders (Bewsell et al. 2007). In this case, the survey provided an understanding of the broad impediments to and perceived benefits of adoption of water quality management. However, this broad understanding was only able to suggest an equally broad class of policy type (e.g. suasion, incentives, regulation). A deeper understanding of the catchment context was required to inform the design of an effective mix and scheduling of specific policy instruments (e.g. code of practice). This reinforces the importance of understanding the complexity of agricultural non-point source pollution and using diverse policy mechanisms to effectively address it (Gunningham and Sinclair 2005; Greiner and Miller 2008; Prokopy et al. 2008, see also Jones et al. 2010). 
The quantitative aspect of the multi-criteria evaluation supported effective policy design by providing structure and transparency to the complex decision making process, and clarified trade-offs. The process accommodated the views of various stakeholders and groups with the ultimate goal of achieving compromise and consensus on the preferred policy scenario (Muller et al. 2009). The deliberative aspect of the multi-criteria evaluation process further enhanced the depth and breadth of understanding of the issues surrounding water quality management in the catchment in this study. This level of understanding was critical for tailoring an effective policy mix and sequence in this case study and for effective design of agricultural non-point source pollution policy in other catchments.

We recognize three main limitations to this study. First, numbers of local landholders attending the two community fora were low (10 and 6). The initial landholder survey captured the breadth of issues around water quality, complemented by the community fora which aimed to deepen understanding of catchment context. Whilst large numbers of participants is not necessarily and advantage when qualitative depth is an objective, with low numbers there is a risk of nuanced responses from individual participants. Second, through both the survey and the DMCE process, participants (especially the more politically savvy dairy farmers), may have been motivated to over-estimate rates of adoption. Thereby, the relative contribution of non-dairy livestock graziers to agricultural non-point source pollution may be understated. Third, we did not consider in detail how some of the policy instruments may be operationalised or implemented on the ground to enable a comprehensive assessment of transaction costs of implementing policy instruments. We recognize that transaction costs may affect the final policy decisions by government.

\section{Conclusion}

In this study, a mix of complementary policy instruments was necessary to address key impediments to the adoption of water quality management. Policy addressing the most important impediments first is more likely to achieve the rates of adoption required to meet water quality and human health targets in water supply catchments. Adoption may be further enhanced by the sequencing of instruments to start with encouragement and end with enforcement, and through the targeting the biggest polluters. The combination of a landholder survey and DMCE process in this study provided catchment-specific contextual information necessary to construct a targeted mix and sequence of policy instruments to achieve widespread adoption of water quality management. The techniques applied in this case study are applicable to the effective mitigation of agricultural non-point source pollution in drinking water supply catchments worldwide.

\footnotetext{
Acknowledgements The authors acknowledge the support of the Commonwealth National Action Plan for Salinity and Water Quality through the South Australian Centre for Natural Resource Management, the SA Environment Protection Authority, SA Water, DairySA, the AMLR NRM Board, and CSIRO's Water for a Healthy Country and Sustainable Agriculture Flagships, and Sustainable Regional Development theme. The authors are grateful to Monique White for conducting the survey, and for the contributions of John Ward, Wendy Proctor, Jacqueline Frizenschaf, Geoff Bradford, Nicole Lewis, Matt Bonnett, Karla Billington, Marcia Sanderson, and the community of the Myponga River catchment. We are also grateful for the comment of Anna Straton, Chris Raymond and Darla Hatton MacDonald and several anonymous reviewers on the draft manuscript.
} 
Open Access This article is distributed under the terms of the Creative Commons Attribution Noncommercial License which permits any noncommercial use, distribution, and reproduction in any medium, provided the original author(s) and source are credited.

\section{References}

ATOMonaghan RM, Kaine G (2008) Information for primary producers 2008. Australian Tax Office, Commonwealth of Australia, Canberra. Accessed online February 28, 2009: http://www.ato.gov.au/content/downloads/NAT1712_06_2008_BW.pdf

BDA Group and EconSearch (2005) An investigation of policy mix options to achieve water quality outcomes in Adelaide's drinking water supply area: consultation draft. Report prepared for the South Australian Environment Protection Authority

Bewsell D, Monaghan RM, Kaine G (2007) Adoption of stream fencing among dairy farmers in four New Zealand catchments. Environ Manag 40:201-209

Bryan BA, Kandulu J (2009) Cost-effective alternatives for mitigating Cryptosporidium risk in drinking water and enhancing ecosystem services. Water Resour Res 45:W08437. doi:10.1029/2008WR007606

Bryan BA, Kandulu J, Deere DA, White M, Frizenschaf J, Crossman ND (2009) Adaptive management for mitigating Cryptosporidium risk in source water: a case study in an agricultural catchment in South Australia. J Environ Manag 90:3122-3134

Chang CL, Hsu TH, Wang YJ, Lin JY, Yu SL (2010) Planning for implementation of riparian buffers in the Feitsui reservoir watershed. Water Resour Manage 24:2339-2352

Collins R, McLeod M, Hedley M, Donnison A, Close M, Hanly J, Horne D, Ross C, Davies-Colley R, Bagshaw C, Matthews L (2007) Best management practices to mitigate faecal contamination by livestock of New Zealand waters. NZ J Agric Res 50:267-278

Connor JD, Ward J, Bryan BA (2008a) How cost-effective are conservation auctions? Aust J Agric Resour Econ 52:303-319

Connor JD, Ward J, Clifton C, Proctor W, Hatton MacDonald DH (2008b) Designing, testing and implementing a trial dryland salinity credit trading scheme. Ecol Econ 67:574-588

Connor JD, Hatton MacDonald DH, Morrison M, Cast A (2009) Evaluating policy options for managing diffuse source water quality in Lake Taupo, New Zealand. Environmentalist 29:348359. doi:10.1007/s10669-008-9197-x

Davies BB, Hodge ID (2006) Farmers' preferences for new environmental policy instruments: determining the acceptability of cross compliance for biodiversity benefits. J Agric Econ 57:393414

de Loë RC, Bjornlund H (2008) Irrigation and water security: the role of economic instruments and governance. Wit Trans Ecol Envir 112:35-42

EPACroke BFW, Beatson PJ, Ashbolt NJ, Deere DA (2008) Myponga watercourse restoration project final report 2000-07. South Australian Environment Protection Authority, Adelaide

Ferguson CM, Croke BFW, Beatson PJ, Ashbolt NJ, Deere DA (2007) Development of a processbased model to predict pathogen budgets for the Sydney drinking water catchment. J Water Health 2:187-208

Government of Western Australia (2010) Small landholder information service. http://www.agric. wa.gov.au/PC_92609.html. Website accessed 24-10-2010

Greiner R, Miller O (2008) Reducing diffuse water pollution by tailoring incentives to region specific requirements: empirical study for the Burdekin River basin (Australia). In: Aravossis K, Brebbia CA, Gomez H (eds) Environmental economics and investment assessment II. WIT, Ashurst, pp 31-42

Greiner R, Patterson L, Miller O (2009) Motivations, risk perceptions and adoption of conservation practices by farmers. Agric Syst 99:86-104

Gunningham N, Sinclair D (2005) Policy instrument choice and diffuse source pollution. J Environ Law 17:51-81

Harrington W, Morgenstern RD, Sterner T (2004) Choosing environmental policy. Resources for the Future Press, Washington

Horan RD, Ribaudo MO (1999) Policy objectives and economic incentives for controlling agricultural sources of nonpoint pollution. J Am Water Resour Assoc 35:1023-1035 
Hrudey SE, Hrudey EJ (2004) Safe drinking water-lessons from recent outbreaks in affluent nations. IWA, London

Huang GH, Xia J (2001) Barriers to sustainable water-quality management. J Environ Manag 61:123

Jansen A, Robertson A (2001) Relationships between livestock management and the ecological condition of riparian habitats along an Australian floodplain river. J Appl Ecol 38:63-75

Jones N, Evangelinos K, Gaganis P, Polyzou E (2010) Citizens' perceptions on water conservation policies and the role of social capital. Water Resour Manage. doi:10.1007/s11269-010-9711-z

Kim S, Gillespie JM, Paudel KP (2008) Rotational grazing adoption in cattle production under a cost-share agreement: does uncertainty have a role in conservation technology adoption? Aust $\mathrm{J}$ Agric Resour Econ 52:235-252

Loomis JB, Allen B (2008) Using non market valuation to inform the choice between permits and fees in environmental regulation. Environ Resour Econ 40:329-337

Lovell ST, Sullivan WC (2006) Environmental benefits of conservation buffers in the United States: evidence, promise, and open questions. Agric Ecosyst Environ 112:249-260

Ma Y, Chen LD, Zhao XF, Zheng HF, Lu YH (2009) What motivates farmers to participate in sustainable agriculture? Evidence and policy implications. Int J Sustain Dev World 16:374-380

MacGregor CJ, Warren CR (2006) Adopting sustainable farm management practices within a nitrate vulnerable zone in Scotland: the view from the farm. Agric Ecosyst Environ 113:108-119

MacKenzie WR, Hoxie NJ, Procter ME, Gradus MS, Blair KA, Peterson DE, Kazmierczak JJ, Addiss DG, Fox KR, Rose JB, Davis JP (1994) A massive outbreak in Milwaukee of Cryptosporidium infection transmitted through the public water supply. New Engl J Med 331:161-167

MacLeod CJA, Scholefield D, Haygarth PM (2007) Integration for sustainable catchment management. Sci Total Environ 373:591-602

Muller NZ, Mendelsohn R (2009) Efficient pollution regulation: getting the prices right. Am Econ Rev 99:1714-1739

Muller N, Tong D, Mendelsohn R (2009) Regulating NOx and SO2 emissions in Atlanta BE. J Econ Anal Poli 9:2-3

Mustajoki J, Hämäläinen RP, Marttunen M (2004) Participatory multicriteria decision analysis with Web-HIPRE: a case of lake regulation policy. Environ Model Softw 19:537-547

NHMRC (2004) Australian drinking water guidelines. National Health and Medical Research Council, Australian Government, Canberra

Pannell DJ (2008) Public benefits, private benefits, and policy mechanism choice for land-use change for environmental benefits. Land Econ 84:225-240

Pannell DJ, Marshall GR, Barr N, Curtis A, Vanclay F, Wilkinson R (2006) Understanding and promoting adoption of conservation technologies by rural landholders. Aust J Exp Agric 46:14071424

Proctor W, Drechsler M (2006) Deliberative multicriteria evaluation. Environ Plan C, Gov Policy 24:169-190

Prokopy LS, Floress K, Klotthor-Weinkauf D, Baumgart-Getz A (2008) Determinants of agricultural best management practice adoption: evidence from the literature. J Soil Water Conserv 63:300 311

Renn O (2006) Participatory processes for designing environmental policies. Land Use Policy 23:3443

Rhodes HM, Leland Jr LS, Niven BE (2002) Farmers, streams, information, and money: does informing farmers about riparian management have any effect? Environ Manag 30:665-677

Romstad E (2004) Methodologies for agri-environmental policy design. In: Brouwer F (ed) Sustaining agriculture and the rural environment: governance, policy, and multifunctionality. advances in ecological economics. Edward Elgar, Cheltenham, pp 56-77

Sarker A, Ross H, Shrestha KK (2008) A common-pool resource approach for water quality management: an Australian case study. Ecol Econ 68:461-471

Smith GR (2007) Logical decisions decision support software: user's manual. Evergreen, USA. http://www.logicaldecisions.com

Sterner T (2003) Policy instruments for environmental and natural resource management. Resources for the Future Press, Washington

Stirling A (2006) Analysis, participation and power: justification and closure in participatory multicriteria analysis. Land Use Policy 23:95-107

Strauss P, Leone A, Ripa MN, Turpin N, Lescot JM, Laplana R (2007) Using critical source areas for targeting cost-effective best management practices to mitigate phosphorus and sediment transfer at the watershed scale. Soil Use Manage 23:144-153 
von Winterfeldt D, Edwards W (1986) Decision analysis and behavioral research. Cambridge University Press, Cambridge

Ward J, Connor JD, Hatton MacDonald D (2008) Designing tradable credit policy for diffuse source salinity ex ante. Soc Nat Resour 21:930-943

Zanakis SH, Solomon A, Wishart N, Dublish S (1998) Multi-attribute decision making: a simulation comparison of select methods. Eur J Oper Res 107:507-529 